\title{
Creative tensions in youth ministry in a congregational context
}

\begin{tabular}{|c|c|}
\hline \multicolumn{2}{|c|}{$\begin{array}{l}\text { Author: } \\
\text { Anita L. Cloete }{ }^{1}\end{array}$} \\
\hline \multicolumn{2}{|c|}{$\begin{array}{l}\text { Affiliation: } \\
{ }^{1} \text { Department of Practical } \\
\text { Theology and Missiology, } \\
\text { Stellenbosch University, } \\
\text { South Africa }\end{array}$} \\
\hline \multicolumn{2}{|c|}{$\begin{array}{l}\text { Note: } \\
\text { This article is published in the } \\
\text { section Practical Theology } \\
\text { of the Society for Practical } \\
\text { Theology in South Africa. }\end{array}$} \\
\hline \multicolumn{2}{|c|}{$\begin{array}{l}\text { Correspondence to: } \\
\text { Anita Cloete }\end{array}$} \\
\hline \multicolumn{2}{|c|}{$\begin{array}{l}\text { Email: } \\
\text { acloete@sun.ac.za }\end{array}$} \\
\hline \multicolumn{2}{|c|}{$\begin{array}{l}\text { Postal address: } \\
\text { Private Bag X1, Matieland } \\
7602 \text {, Stellenbosch, South } \\
\text { Africa }\end{array}$} \\
\hline \multicolumn{2}{|c|}{$\begin{array}{l}\text { Dates: } \\
\text { Received: } 05 \text { Dec. } 2013 \\
\text { Accepted: } 30 \text { June } 2014 \\
\text { Published: } 06 \text { Feb. } 2015\end{array}$} \\
\hline \multicolumn{2}{|c|}{$\begin{array}{l}\text { How to cite this article: } \\
\text { Cloete, A., 2015, 'Creative } \\
\text { tensions in youth ministry } \\
\text { in a congregational context', } \\
\text { HTS Teologiese Studies/ } \\
\text { Theological Studies 71(2), } \\
\text { Art. \#2107, } 7 \text { pages. http:// } \\
\text { dx.doi.org/10.4102/hts. } \\
\text { v71i2.2107 }\end{array}$} \\
\hline \multicolumn{2}{|c|}{$\begin{array}{l}\text { Copyright: } \\
\text { (C) 2015. The Authors. } \\
\text { Licensee: AOSIS } \\
\text { OpenJournals. This } \\
\text { work is licensed under } \\
\text { the Creative Commons } \\
\text { Attribution License. }\end{array}$} \\
\hline \multicolumn{2}{|l|}{ Read online: } \\
\hline 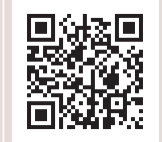 & $\begin{array}{l}\text { Scan this QR } \\
\text { code with your } \\
\text { smart phone or } \\
\text { mobile device } \\
\text { to read online. }\end{array}$ \\
\hline
\end{tabular}

Since the recognition of youth as a social category, several approaches to youth ministry developed. One of the approaches, namely the inclusive congregational approach to youth ministry, will be critically reflected on in this article. The aim of this article is to indicate what the implications of this approach are for congregational ministry. It is argued that the inclusive congregational approach to youth ministry could lead to certain creative tensions in youth ministry as an integral part of congregational ministry. Therefore the article identifies and discusses specific creative tensions that could be present in youth ministry where the inclusive congregational approach to youth ministry is taken as the point of departure. Creative tension is here understood as a source of creative energy that informs and guides ministry. Although the different tensions may cause uneasiness, with the spontaneous response to release them, it is argued that it should rather be kept intact in order to inform and maintain a creative process of ministry.

\section{Introduction}

The first section of the article offers a concise explanation of the theological foundations of the inclusive congregational approach to youth ministry, followed by a summary of the main critique against it. The implications of the inclusive congregational approach to youth ministry are described as certain creative tensions that could be in service of the ministry, rather than stumbling blocks or hindrances. The main arguments are that youth ministry and congregational ministry should rather be complementary and not separated ministries. Furthermore, if the aim of youth ministry is spiritual formation, it should be a communal and intergenerational process, where different age groups, seek and discern God's will together. Although events could be of great value, it should not be the ultimate goal of youth ministry, but should be in service of the theological vision of the ministry. Youth ministry therefore should be understood and implemented as a process that is theologically grounded and motivated and does not merely consist of events to entertain the youth. Distance and closeness in youth ministry are proposed in order for the youth to find their own identity and spiritual journey with and away from adults. Lastly, it is argued that youth ministry takes place between human and divine action as we join the active God in the world as his representatives with the youth.

\section{The inclusive congregational approach to youth ministry}

Congregational involvement was part of the development of youth ministry, especially in South Africa. The inclusive congregational approach is proposed by a South African theologian, Malan Nel (2000) who has done research for several years on congregational development, evangelism, youth ministry and Christian education. In order to give some insight into this approach, a summary of the theological foundation thereof, as well as the main critique against it, will be provided. According to $\mathrm{Nel}(2000: 8)$ one of the greatest defects of youth ministry is the lack of a sound theological foundation. Therefore the theological grounding of this approach is of importance to grasp the basis thereof. The covenant and relational perspective postulates that God wants to be known and therefore takes the initiative and maintain his ongoing relationship with the human race. God uses the relationship between people through the working of the Holy Spirit to reveal himself to us (Nel 2000:13-14). The youth is included in this ongoing relationship between God and humanity. The congregation is seen as a key space or context of the corporate thinking of the Bible, where families and groups play an important role (Nel 2000:16). The youth should therefore be included in the community of faith as a primary space for faith formation. Moreover, the youth is in need of relationships, and congregations should provide relationships that contribute to their spiritual growth through belonging to a serving community. Nel (2000:21) describes the congregation as an agogical space where the youth is accepted for whom they are, becoming who they are already in Christ. Although change could sometimes be painful and difficult, the congregation should be a place where change is motivated and facilitated as a natural part of ministry ( $\mathrm{Nel} \mathrm{2000:23).}$ 
Embedded in the congregational or corporate sphere, the family is singled out as smaller unit to which God grants a special hermeneutic function where children can understand who God is and how God deals with people (Nel 2000:19). Nel (2000:20) does not argue that God cannot work despite the brokenness of the family or in other forms of relationships, but emphasises the special context the family provides, where understanding can take place in a secure, natural and differentiated way. Nel (2000:63) understands the goal of youth ministry as closely linked to the theological foundations of youth ministry. As such he argues that the goal of God with the congregation is God's goal with the youth as an essential part of the congregation (Nel 2000:64).

In sum the inclusive congregational approach to youth ministry is grounded in the covenant according to which God initiates and sustains the relationship with his creation. In this ongoing relationship between God and the human race he includes us all, young and old, in a special way to be agents of this relationship where we could encounter God. The congregation and family are singled out as primary agents of relationships where the youth should be nurtured. This approach does not view the youth as passive objects of ministry, but rather as active participants that could and also should minister. This is clear from Nel's (2000:97) definition of youth ministry, in which he indicates that it takes place with and through the youth as an integral part of the local church. The inclusion of youth ministry as an integral part of the congregational ministry is not because of pragmatic reasons, but is grounded in the theological understanding of God's inclusion of all the human race through the covenant and the congregation as a manifestation of the togetherness of God's people on earth. This approach does not start with who young people are, how important that may be, but with whom and what the church is. Therefore it is about finding a place for the youth in the existing congregational ministry and not about another ministry. The approach is against the reduction of youth ministry to catechesis or organised work with the youth, as it does not see youth ministry as a supplement to the congregation, but as an essential part thereof ( $\mathrm{Nel} \mathrm{2001:18).}$

\section{Implications of the inclusive congregational approach}

The implications of the inclusive congregational approach are that youth ministry is wholly the congregation's responsibility and therefore part of the comprehensive ministry of the congregation ( $\mathrm{Nel} 2000: 77)$. The consequences of this approach could be summarised as follows:

- Youth ministry should not be thought of as a separate ministry from the congregational ministry, but is an integral part thereof.

- The uniqueness and distinct phase of the youth should be acknowledged through differentiation, but as part of the congregational ministry and should not be the reason for separation and isolation.
- The youth should not be ignored or neglected, but incorporated in every part of the ministry, because the youth is the local churches' responsibility (Nel 2000:78-79).

\section{Critique against the inclusive congregational approach}

There is valuable critique against this approach which is worthy to be taken note of. Most researchers in the book Four views of youth ministry and the church (Senter III 2001) have appreciation for the theological justification of the inclusive congregational approach. Although the theological grounding is solid and insightful, the following could be regarded as major points of critique against it:

- The lack of a good explanation of what differentiation means and how it should be implemented. In others words, when and how much should the youth be together with adults and when should they be apart? Does this approach not also mean segregation in a more controlled fashion? (Nel, in Senter III 2001:33).

- The growing cultural gap between adults and the youth is not taken seriously enough and reckoned with, as it seems that the youth is almost viewed as a different kind of adult.

- It seems that the approach is only concerned with church youth and not unchurched youth, which speaks to the missional calling of the church (Black 2001:22-25; Clark 2001: 28-29).

- Adults could dictate how the approach should be implemented without or with limited contribution from the youth, which could have the opposite effect, namely alienating the youth from the congregation, instead of including them (Nel, in Senter III 2001:32).

- Large congregations could find it difficult to implement this approach (Nel, in Senter III 2001:34).

The critique seems to focus mainly on the pragmatic side of the approach, in other words how it works in practice. Moreover, is this approach really possible in practice, when taken into account, especially who the youth is and the changing cultural context in which ministry takes place? In the following section I will suggest that this approach should not be discarded, especially on grounds of pragmatic issues raised as part of the critique. I will suggest that this approach could lead to certain creative tensions which have direct bearing on the critique raised against this approach. It is, however, argued that these creative tensions could be in service of ministry.

\section{What is meant by creative tension?}

Creative tensions are here understood as a product or result of the interrelatedness and connectedness of ministry as a complex system. These two seemingly opposite positions keep the tension intact and create energy for creative innovation through ministry. Therefore the ideal seems not to release the tension, but rather to keep it intact and let it work for something greater and better than the current reality. It seems that one tension reveals another tension 
and so gives way for a creative movement. In the following section four creative tensions with regard to youth ministry in a congregational context will be identified and discussed.

\section{Youth ministry as integral part of congregational ministry}

Seibel and Nel (2010:1) present an insightful view on the church as intergenerational community that should 'strive to sustain its witness throughout all generations'. This mission of the church however is not without challenges as will be indicated in this article, precisely because it entails the incorporation of different generations into the community of faith. Therefore one of the main concerns about the inclusive congregational approach is how the youth and adults, representing different generations, should and could exist together in being church in a changing context. A related question is whether youth ministry and congregational ministry are two separate ministries. It could be helpful to respond to these questions by saying something on the development of youth ministry. Before the youth was acknowledged as a distinct social category, ministry was geared towards the family as there were no sharp distinction and separation between adults and children ( $\mathrm{Nel} \mathrm{2000:51).}$ The focus on the family in ministry was a reflection of how society was structured, as children were working alongside their parents or adults. This however changed and most societies are now marked by the increasing separation of the youth and adults. This increasing separation of the youth and adults resulted in a distinct way of living by the youth, which could be described as youth culture (Cloete 2012:1). It is in this context that youth ministry started to focus on an age-specific ministry, where ministries specialised for different age groups were developed (Root 2007:30). The development of youth ministry in South Africa was marked by congregational involvement. Youth ministry could therefore be viewed as the church's response to the youth as cohort (Nel 2000:53; Root 2007:28), which started attending separate institutions, of which the school was the most significant (Root 2007:32). In the context of increased separation between the youth and adults, age-specific ministry developed, where specialised ministries were offered to different age groups. Age-specific ministry seems to be one of the main reasons why youth ministry developed into a separate ministry, segregated and isolated from the congregational ministry (DeVries 1994:41). Mark DeVries (1994) succinctly describes the separation of the youth, especially in a church context, as follows:

Sadly enough for many teenagers, the place they are the most segregated from the world of adults is their church. And churches with the more 'successful' youth programs seem to particularly exacerbate this problem. (p. 43)

Youth workers however, soon realised that working with the youth, separated from adults, especially the parents, is fatal (DeVries 1994:85).

Although there may be some positives with regard to age-specific ministry, the downside is more severe, as it separates people in the church where they should be together amidst diversity (Cloete 2012:75). Ministry that separates people according to age or social status prevents Christians from hearing the insights from the entire faith community. This division according to age in ministry is not found in Scripture. This does not mean that peer groups should not meet from time to time to discuss spiritual matters pertinent to them, but congregational ministry should rather promote multi-generational worshipping communities where significant contact with different age groups is possible (Gibson 2004:9). If youth ministry wants to be of value to the youth, it must foster communities across generational lines. 'The community of faith could be a primary context where the youth learn to live within a community and discover themselves and God through belonging' (Cloete 2012:75).

Reflecting on the aim or purpose of ministry could give guidance in formulating an informed response to the abovementioned questions. Kenda Dean (2001:15-16) argues that, although it is important to adapt and stay relevant in a changing culture, even more important is the question why we do what we do or whom we do it for. Nel (2000:63) also notes that the purpose (why we minister) of youth ministry should be embedded in the goal of building up the local church. In the light thereof, Nel (2000) describes the purpose of youth ministry in relation to the church as follows:

God's purpose with the congregation is also God's purpose with the youth as an essential part of the congregation. The purpose of youth ministry should be aligned with this purpose of God for us and with his church. (p. 64)

The building up of the congregation as the aim of youth ministry, Nel (2000:64) explains '... as growing and searching together'. This process of growing and searching together could be understood as spiritual formation. Christian spiritual formation is a communal project of seeking God's will together across generational lines; therefore youth ministry should be intergenerational. At the same time the uniqueness of the different generations should be acknowledged and valued. Intergenerational ministry should therefore engage and celebrate difference and diversity. As Dykstra (2005:39) puts it: 'Faith and the life of faith are communal before they are individual.' Westerhoff (1976:53) states: '[T]rue community necessitates the presence and interaction of three generations'. He describes the third generation as the generation of memory, the second as the generation of the present, and the first as the generation of vision. All three generations are needed in the community of faith, because contact with others longer on this road is not optional, but critical. Being together as different generations is of importance to develop a shared religious language that is accessible for all and necessary for faith formation (Dean 2010:139). If the church is not able to function as an intergenerational community it leads to the reduction of tradition according to the understanding and expression of faith by one, mostly the older generations. The reduction of tradition represents a reduced understanding of the gospel and is closely associated with the sinful human nature to control (Seibel \& Nel 2010:2). One of the devastating results 
is the isolation and marginalisation of new generations, causing them to lose interest in the church and eventually leaving the church (Seibel \& Nel 2010:2).

In light of the arguments above, youth ministry should not be viewed as a subsection of congregational ministry to ensure that, eventually, the congregation continues. Put differently: youth ministry is not about saving the local congregation for tomorrow. This view on youth ministry originates mostly from the perception that the youth are the leaders and the church of tomorrow (Nel 2000:63). If youth ministry is only seen as instrumental in saving the local congregation, it could lead to the reduction of youth ministry to the marketing section of the congregation. Then youth ministry becomes merely a display of what the congregation (denomination) has to offer. Furthermore, if the youth is only acknowledged because of their possible value for tomorrow, they are not viewed as valued members of the faith community who could make a valuable contribution today. Therefore I will argue that the youth could only be church tomorrow if they are church today. The congregation is about the youth as it is about anyone else, and therefore the goal of the local church should also be embedded in the praxis of youth ministry. In the words of $\mathrm{Nel}$ (2000):

Youth ministry is not about finding an extra place for yet another ministry, but finding a place for the youth within every ministry, and among the people at whom the ministries are directed: the people to whom God comes by means of the ministries. (p. 83)

Youth ministry as an integral part of congregational ministry, where the youth plays an irrepressible and irreplaceable part, has the ability to reimagine being church today (Dean 2011b:35). Because young people demand that the church addresses them in their specific cultural and development experiences as adolescence, youth ministry could serve as a laboratory where we can learn to contextualise ministry (Dean 2011a:20). In order for that to happen, the congregation should serve as agogical space where change is expected and valued, as well as diversity celebrated (Nel 2000:23).

\section{Closeness and distance in youth ministry}

I have argued that youth ministry should be an integral part of congregational ministry, despite the increasing separation of the youth and adults in society. Due to the tension caused by the different needs and spiritual expression of the different generations, age-specific ministry seems to be much easier and even more relevant. Ward (1999:129) explains that age-specific ministry, as well as youth ministry through para-church organisations in most cases, is a way of escaping church. The church is viewed as incapable of providing in the needs of the youth, and therefore they just tolerate the church or try to escape from it. Ward (1999:129) however, warns that it is not possible to escape from the church, because youth ministry grows from a partnership in the gospel and is therefore irrevocably connected to the church.
The question then begs how the youth could be engaged with as part of congregational ministry. I would like to propose that youth ministry, as an integral part of the congregational ministry, should operate within the creative tension of distance and closeness. Firstly, it implies that all (young and old) are taken seriously and that there are opportunities for all to participate in ministry. Furthermore, such a ministry should be able to engage and appreciate diversity and not be destroyed by it. This kind of ministry helps to foster the understanding that ministry is not about youth or adults, but rather about the body of Christ according to 1 Corinthians 12:19-20. In the body of Christ there are different parts that play different roles, but it is still one body. Being part of the body of Christ therefore implies unity amidst diversity and difference. Sameness in our expression of faith should therefore not be expected, but rather variety.

Secondly, it is important for young people to break free from safe environments to find their own place and space in the world. In other words, the youth needs to find their own identity and spiritual life with and away from adults. Youth ministry should create a space where the youth can find its own voice, its own spiritual journey, and move away from the known to unknown places of life, and be true to the faith they have been taught and experienced at home. Flomsbee (2007:41) describes this as a faith that is mobile - a faith that they can take with them wherever they go. Youth ministry as an essential part of congregational ministry should therefore facilitate and foster independence but not isolation.

The creative tension of closeness and distance does not pertain only to physical presence or absence, but also refers to the way we are together. When together, each generation needs to be appreciated for who they are and there should be openness to different ways of expressing spirituality together. The aim of youth ministry should therefore never be limited to the known boundaries of the congregational life, but should prepare the youth to live anywhere in any circumstances according to what they believe. In short, youth ministry should contribute towards assisting the youth in maturing in faith; integrate what they believe in their whole life and live up to their deepest convictions anywhere. In doing so, youth ministry is about expression and living what they believe in and not only talking about it (Flomsbee 2007:33).

\section{Youth ministry as process versus youth ministry as an event}

Different events are sometimes regarded as mandatory happenings if youth ministry is to be considered valuable and effective. Age-specific ministry is often characterised by events resulting in the entertainment emphasis in youth ministry (Hryniuk 2005:143). Youth ministries are therefore mostly evaluated on grounds of the series of events planned (Jones 2001:349). Neder (2001:344), however, warns that it is considered unwise to fall into the trap of emphasising programs over relationships in youth ministry. In the same vein Jones (2001:349) argues that, although programmes are important, it should not be the foundation of youth ministry. 
Cook (1995:102) concurs and explains that programs could provide a means of access to form meaningful relationships with the youth. Dean (2010:123) shares this understanding regarding the role of programmes in relation to relationships, and argues that people are the best translators of faith, not programmes. Jones (2001:350) proposes intentional and purposeful planning of events if the youth is to mature in their faith. According to Dean (2011b:34), the most noticeably change in youth ministry is the diminished role of programmes and events in favour of relationships and spiritual practices. Flomsbee (2007:17) notes that the moving away from prioritising programmes implies that youth ministers and volunteers should not see themselves as people that keep programmes going, but rather as spiritual directors in the lives of young people. This further implies that in youth ministry we should first think theologically before methodologically (Flomsbee 2007:21).

This obsession with events could be linked to the tendency of ministry (specifically youth ministry) to become a series of events that should be relevant and entertaining. The issue of relevance is a difficult and even misleading one, because how do we evaluate relevance? How do we stay true to the unchanging gospel in an ever-changing context and culture? Taking the context seriously could be of great help in our attempts to be relevant. We could get closer to being relevant by not confusing being relevant with being popular, famous or merely interesting, but rather being real and consistent with what we proclaim and live. Being relevant could be to value substance more than size, quality more than quantity. Being relevant could mean not having clear-cut answers, although it may sometimes seem that it is all the youth wants, but rather to be able to formulate better questions together. Hoffmeyer (2008:362) suggests an interrogatory theology as suitable for youth ministry, explaining that 'good questions can open new territory to consider, as much as strong light illumines previously unseen territory'. This kind of theology is not about youngsters' unbelief or disbelief in God, but gives opportunity for probing into the richness and mystery of God. It is a theology where people learn to become good questioners; in other words, to ask questions that open dialogue and move beyond fixed positions to new revelations. It creates a process where questions are not seen as problems, but as open-ending processes of faith seeking understanding (Hoffmeyer 2008:366). Youth ministry should therefore create a space for serious dialogue where questions are valued, because that could pave the way for the youth to engage with the existential issues they are facing every day. Moreover, it could lead to a move away from a theology that only informs (cognitive) and is one-directional, to a theology where dialogue and creative participation (integration and experience) of all generations are valued.

How we think about and do youth ministry is most probably the clearest mirror of how we understand ministry at large. Ministry is or should be a process and not a program or an event. That implies that it is not as clear-cut and neat as an event, but a more unpredictable ongoing process which entails the interaction and development of many complex systems. On the other hand, it does not imply that there is no place for events in ministry. However, ministry is not the sum total of full calendars of events without a theological vision and foundation that undergird them, or a context analysis that takes the here and the now serious every step of the way. Youth ministry should always be guided by serious theological reflections that provide the vision for the ministry, and events should be in service of that vision.

\section{Youth ministry as theological task that happens between divine action and human action}

Nel (2001:8) points out that youth ministry often lacks a sound theological foundation. Dean (2001a:28-29), however, notes that the moment of truth for youth ministry was when especially youth ministers realised that it was not about entertaining youth, but facilitating processes that assist them to mature in faith. This moment of truth developed into a turning point in youth ministry where theological reflections became the norm instead of the exception (Dean 2011b:15). In other words, youth ministry is now recognised and practised as a theological task. This, however, does not mean that there was no theological reflection at all or that youth ministers did not care about theology, but their self-conception and actions were rarely informed by significant theological reflection. Today however, theologically reflection in youth ministry is needed and normative (Dean 2011a:16). As Root (2011:40) explains, theological reflection is nothing more than reflections on God's action. In other words, in youth ministry we have to reflect on God's ministry in the world. Practical theology provides youth ministry with an intentional process of reflections which allows for creative responses to the particular context of the youth (Dean 2011a:19). Practical theology, as the reflection on Christian life, focuses on the moments, situations and practices where God's actions intersect our actions and transform human actions into something holy and life-giving (Dean 2011a:17). Practical theology thus is the theological discipline that zooms in on human action in service of the Kingdom - on human action as communicative practice in service of the gospel.

Despite these developments it still seems we became so caught up with the word 'Youth' in youth ministry that we seem to lose sight of the fact that it is still ministry. In the words of Kenda Dean (2011a:20): 'Ministry with young people is after all ministry and not so different from ministry with anybody else.' Youth ministry as a theological task takes place when divine actions and human actions meet as we join the active God in the world. Ministry, however, does not imply that we bring God to the world, but rather focus on God's graceful inclusion of mankind in his ongoing action. The fact that we can participate in Gods ongoing ministry, points to the Incarnation that celebrates humanness and does not condemn it. Therefore, in our theological reflection we need to be reminded about this mystery that God has entrusted us with the privilege to speak and act in his name. One of the greatest challenges ministers face, especially 
within youth ministry, is not to build the ministry around them. Nel (2000:116) refers to the spirit of followership of the youth which makes youth ministry leadership easy and problematic at the same time. Ministry, however, is never ours - it has nothing to do with claiming certain positions, but everything to do with pointing to Jesus in everything we do (Maas 2001:239; Ward 1999:1310). Dean (2011a:19) even refers to making ministry about us, as sin.

Theological reflection, however, keeps the focus on God in youth ministry and makes congruency possible between what we believe and how we conduct our lives (Dean 2001:29). In ministry we must never hide behind our humanness, because that is the condition God finds fit to use us in. Youth ministry is surely one of the most challenging and rewarding ministries, simply because of the formative phase it is. Moreover, the youth are bombarded with different life choices, especially via the media. What we do in ministry can offer an alternative voice in the media-soaked world youngsters live in (Cloete 2012:4). This voice of ministry does not have to act out of fear, because we are only servants of God in ministry. Hryniuk (2005:143-144) asserts that the entertainment emphasis in youth ministry is borne out of fear of losing the youth to the world that is viewed as more interesting, whilst the church is boring and irrelevant. The theological basis of the inclusive congregational approach could help us to understand and practice youth ministry as ministry and not as event. The theological foundation of the inclusive congregational approach could inform and guide youth ministry where the starting point is who we are in Christ through the covenant and relationships. Our togetherness, amidst difference and diversity is not a burden or an obstacle, but a God-given opportunity.

\section{Conclusion}

The aim of the article is to indicate what the implications are of implementing the inclusive congregational approach to youth ministry. This is done by giving a concise overview of the theological basis of this approach, as well as the main critique against it. Certain creative tensions are identified as consequences of taking the congregational approach as point of departure in youth ministry. Four creative tensions are identified, namely: youth ministry as integral part congregational ministry; closeness and distance in youth ministry; youth ministry as a process versus youth ministry as an event; and youth ministry as a theological task that happens between divine and human action.

It is concluded that youth ministry is as much about adults as it is about the youth, therefore youth and congregational ministry should be complementary, intergenerational and a space where diversity is valued and celebrated. Youth ministry that is theologically grounded is more than entertaining programmes and events. It creates opportunities for rigorous discussion and dialogue where all partners' participation (young and old) are valued. In youth ministry we also join the active missional God as his representatives with the youth. Therefore ministry should never be about us, but we should point to Jesus in all that we do. Although we are mere clay pots, ministry celebrates humanness, because through God's grace we have the opportunity to be part of his ongoing action in the world, through ministry. The inclusive congregational approach, however, asks for leadership that understands and believes in the value of community across generational lines. To be together as different generations will not be easy, and therefore necessitates a process characterised by patient and endurance. Youth ministry is an ecclesiological matter and therefore intertwined with the identity and mission of the church in the world. As such youth ministry is not primarily about winning the youth for the church, but rather about preparing the youth to go out from the church to witness in the world as the church. New generations should therefore be welcomed and empowered to shape tradition and not be mere observers and receivers of traditions that do not make sense to them. If that is neglected the church becomes a playground for power struggles between different generations that dishonours the good news of freedom that the church proclaims and should be an expression of. Therefore youth ministry as embedded in congregational ministry is not merely a strategy, but essential for being a community of faith. The intergenerational nature of the congregation is therefore not something that needs to be done, but rather something that congregations become as an expression of God's grace that includes and does not exclude. In order to be able to connect with the cultural reality of every generation 'the church must engage in a reflective culture task of "fluid-traditioning"' (Seibel \& Nel 2010:1). This process implies that members are not receivers of tradition but participants in creating tradition for the future generations. Furthermore, the church as an intergenerational community does not entail a static way of being bound by tradition, but is a vital and vibrant community that treasures traditions and therefore renews itself constantly. The intergenerational nature of the church requires of the members to keep tradition alive in a way that does not allow tradition to be frozen, but rather unleashes a dynamic process of creating tradition together. In doing so, the church and its traditions do not only belong to the past or previous generations, but also to the future and the coming generations. Different generations are therefore essential to enable the church to recast its faith and practices in ways that are meaningful for all generations (Seibel \& Nel 2010:4).

\section{Acknowledgements Competing interests}

The author declares that she has no financial or personal relationship(s) that may have inappropriately influenced her in writing this article.

\section{References}

Black, W., 2001, 'Response from a missional perspective', in M.H. Senter III (ed.), Four views of youth ministry and the church, pp. 39-71, Zondervan Publishing House, Grand Rapids, MI.

Clark, C., 2001, 'Response from a missional perspective', in M.H. Senter III (ed.) Four views of youth ministry and the church, pp. 77-109, Zondervan Publishing House, Grand Rapids, MI. 
Cloete, A., 2012, 'Youth culture, media and sexuality: What could faith communities contribute?', HTS Teologiese Studies/Theological Studies 68(2), 6 pages. http://dx.doi.org/10.4102/hts.v68i2.1118

Cook, C., 1995, 'Programme and relationships in youth ministry', in P. Ward (ed.), Relational youth work: Perspectives on relationships in youth ministry, pp. 92-104, Lynx Communications, Sandy Lane West.

Dean, K., 2001, 'Theological rocks - First things first', in K. Dean, C. Clark, \& D. Rahn (eds.), Starting right: Thinking theologically about youth ministry, pp. 27-41, Zondervan Publishing House, Grand Rapids, MI.

Dean, K., 2010, Almost Christian: What the faith of our teenagers are telling the American church, University Press, Oxford.

Dean, K., 2011a, 'Introduction', in A. Root \& K. Dean (eds.) The theological turn in youth ministry, pp. 13-24, Intervarsity Press, Westmont, IL.

Dean, K., 2011b, 'The new rhetoric of youth ministry', in A. Root \& K. Dean (eds.), The theological turn in youth ministry, pp. 27-37, Intervarsity Press, Westmont, IL.

DeVries, M., 1994, Family-based youth ministry: Reaching the been there, done that generation, Intervarsity Press, Downers Grove, IL.

Dykstra, D., 2005, Growing in the life of faith: education and practices, 2nd edn., John Knox, Louisville, KY.

Flomsbee, C., 2007, A new kind of youth ministry, Zondervan, Grand Rapids, MI.

Gibson, T.S., 2004, 'Congregational connectivity: The key to keeping youth in the church, Journal of Youth Ministry 3(1), 7-14.

Hoffmeyer, J.F., 2008, 'Interrogatory theology', Dialogue: A Journal of Theology 474 361-367.

Hryniuk, M., 2005, 'Creating space for God: Toward a spirituality of youth ministry', Religious Education 100(2), 139-156. http://dx.doi.org/10.1080/ ministry', Religious
Jones, K., 2001, 'Acting wisely: Routines, trips and events', in K. Dean, C. Clark \& D. Rahn (eds.). Starting right: Thinking theologically about youth ministry, pp. 349-377, Zondervan Publishing House, Grand Rapids, MI.

Maas, R., 2001, 'Theological framework for youth ministry: Repentance', in K. Dean, C. Clark \& D. Rahn (eds.), Starting right: Thinking theologically about youth ministry, pp. 229-243, Zondervan Publishing House, Grand Rapids, MI.

Neder, C.N., 2001, 'Acting wisely: Programs, routines and disciplines', in K. Dean C. Clark \& D. Rahn (eds.), Starting right: Thinking theologically about youth ministry, pp. 341-349, Zondervan Publishing House, Grand Rapids, MI.

Nel, M., 2000, Youth ministry: An inclusive congregational approach, Kitskopie, Pretoria.

Nel, M.H., 2001, 'The inclusive congregational approach to youth ministry', in M.H. Senter III (eds.), Four views of youth ministry and the church, pp. 1-35, Zondervan Publishing House, Grand Rapids, MI.

Root, A., 2007, Revisiting relational youth ministry: From a strategy of influence to a theology of incarnation, Intervarsity Press, Downers Grove, IL.

Root, A., 2011, 'God is a minister. Youth ministry as fundamentally theological', in A. Root, \& K. Dean (eds.), The theological turn in youth ministry, pp. 37-48, Intervarsity Press, Downers Grove, IL.

Seibel, C.L. \& Nel. M., 2010, 'Generation X, intergenerational justice and renewal of the traditioning process', HTS Teologiese Studies/Theological Studies 66(2) 7 pages. http://dx.doi.org/10.4102/hts.v66i2.876

Senter, M.H. III, 2001, 'Response from a strategic perspective', in Four views of youth ministry and the church, pp. 113-148, Zondervan Publishing House, Grand Rapids.

Ward, P., 1999, God at the mall: Youth ministry that meets kids where they are at, Hendrickson Publishers Inc., Peabody, MA.

Westerhoff, J.H., 1976, Will our children have faith?, The Seabury Press, New York, NY. 